\title{
Zasada ogólna czynnego udziału strony w postępowaniu administracyjnym a prawa strony $\mathrm{w}$ postępowaniu w sprawach załatwianych milcząco
}

\section{Wprowadzenie}

Warunkiem skutecznego wszczęcia i prowadzenia administracyjnego postępowania jurysdykcyjnego jest istnienie podmiotu, przedmiotu oraz podstawy prawnej dla działań organu, składających się na materialnoprawny aspekt sprawy. Sprawa, jako przedmiot postępowania administracyjnego, powstaje, gdy "prawo materialne żąda swojej konkretyzacji ze względu na stan faktyczny. Jest więc ona niepowtarzalnym splotem prawa i faktu, w który uwikłane są dwa podmioty: organ administracyjny i strona"1 ${ }^{\prime \prime}$ Główna rola w postępowaniu administracyjnym przypada organowi administracji publicznej, który prowadzi postępowanie, kreując w nim prawa i obowiązki stron postępowania mocą aktu stanowiącego finalny "produkt" postępowania. Takie cechy postępowania administracyjnego w sposób zasadniczy rzutują na określenie w nim pozycji procesowej strony zarówno poprzez określenie jej uprawnień o charakterze ściśle procesowym, jak i uprawnień o charakterze materialnym ${ }^{2}$. Podkreśla się $\mathrm{w}$ doktrynie, że wyniesienie do rangi zasady ogólnej w Kodeksie postępowania administracyjnego ${ }^{3}$ prawa strony do

\footnotetext{
${ }^{1}$ Por. J. Zimmermann, Administracyjny tok instancji, Kraków 1986, s. 13.

${ }^{2}$ Por. H. Knysiak-Molczyk, Uprawnienia strony w postępowaniu administracyjnym, Zakamycze 2004, s. 12.

${ }^{3}$ Ustawa z dnia 14 VI 1960 r. Kodeks postępowania administracyjnego (tekst jedn. Dz.U. 2018, poz. 2096), dalej „k.p.a.” lub „Kodeks”.
} 
czynnego udziału w postępowaniu stanowi sposób na eliminację wielu negatywnych skutków procesu inkwizycyjnego ${ }^{4}$. Prawo do czynnego udziału w procesie stwarza stronie możliwość podejmowania czynności w obronie jej interesów ${ }^{5}$. Czynny udział w postępowaniu w sprawie chroni przed arbitralnością i omnipotencją władzy.

Szczególną wrażliwość na prawa strony w procesie dostrzega się w aktach prawa Unii Europejskiej (UE). Artykuł 41 ust. 1 i 2 Karty praw podstawowych Unii Europejskiej ${ }^{6}$ nakłada na organy i instytucje UE obowiązek zapewnienia obywatelowi wysłuchania przed podjęciem jakiegokolwiek działania mogącego mieć negatywny wpływ na sytuację tej osoby, prawo dostępu do akt sprawy oraz prawo do poznania motywów rozstrzygnięcia. W art. 16 ust. 1 Kodeksu Dobrej Praktyki Administracyjnej ${ }^{7}$ stwierdzono natomiast, że w przypadkach dotyczących praw i interesów jednostek urzędnik zapewnia przestrzeganie prawa do obrony na każdym etapie postępowania zmierzającego do wydania decyzji. Zgodnie z art. 16 ust. 2 tego Kodeksu w przypadkach, w których ma zostać wydana decyzja dotycząca praw lub interesów jednostki, osoba ta ma prawo, przez podjęciem decyzji, przedstawić swoje uwagi na piśmie i w razie potrzeby przedstawić ustnie swoje spostrzeżenia. Z kolei w załączniku do rezolucji Komitetu Ministrów Rady Europy z 28 września 1977 r. (77)31 o ochronie jednostki w sprawach rozstrzyganych aktami organów administracji ${ }^{8}$ wśród podstawowych zasad określających pozycję jednostki względem organu administracji publicznej wskazuje się: (1) prawo do wysłuchania - każdy może przedstawić fakty, argumenty oraz dowody, które zostaną rozważone w sprawie rozstrzyganej aktem administracyjnym obciążającym jednostkę lub ograniczającym jej prawa i wolności; (2) prawo do uczestnictwa w postępowaniu, które jednostki dotyczy; (3) prawo dostępu do informacji o przebiegu sprawy, dowodach i innych okolicznościach postępowania; (4) prawo do wsparcia i reprezentacji; (5) prawo do przedstawienia przez organ

\footnotetext{
${ }^{4}$ Por. M. Wierzbowski, Rozdział II Zagadnienia ogólne. § 5. Zasady ogólne, w: Postępowanie administracyjne - ogólne, podatkowe, egzekucyjne i przed sądami administracyjnymi, pod red. M. Wierzbowskiego, Warszawa 2008, s. 25.

${ }^{5}$ W. Chróścielewski, P. Dańczak, J.P. Tarno, Postępowanie administracyjne i postępowanie przed sąami administracyjnymi, Warszawa 2018, s. 49.

${ }^{6}$ Dz.Urz. UE C 202/389 z 7 VI 2016 r.

${ }^{7}$ Por. decyzja Parlamentu UE z 6 IX 2001 r. w sprawie Kodeksu Dobrej Praktyki Administracyjnej (Dz.Urz. UE C 285/03 z 29 IX 2011 r.).

${ }^{8}$ Tekst rezolucji został zamieszczony w pracy: T. Jasudowicz, Administracja wobec praw człowieka, Torun 1996.
} 
uzasadnienia - jeżeli akt ingeruje w sferę praw, interesów, wolności jednostki; (6) prawo do uruchomienia środków ochrony ${ }^{9}$.

Nie wzbudza wątpliwości, że wyartykułowane prawa strony są respektowane w toku ogólnego postępowania administracyjnego i pokrywają się zakresowo zarówno z prawami wywodzonymi z art. 10 § 1 k.p.a., jak i ich uszczegółowieniem w dalszych przepisach Kodeksu.

Na tle tak pojmowanych uprawnień strony w procesie administracyjnym wyłania się zagadnienie jej pozycji procesowej w postępowaniu w sprawach załatwianych milcząco. Na mocy nowelizacji k.p.a. Ustawą z dnia 7 kwietnia 2017 r. o zmianie ustawy - Kodeks postępowania administracyjnego oraz niektórych innych ustaw ${ }^{10}$ nastąpiło ujęcie w ramy obowiązywania Kodeksu instytucji milczącego załatwienia sprawy. Ustawodawca zastrzegł swoisty reżim procesowy dla spraw załatwianych milcząco, oparty na formule uproszczonego - odformalizowanego postępowania, z równoczesnym wyznaczeniem granic dla praw strony $\mathrm{w}$ procesie. Zgodnie z art. 122d § 1 k.p.a. do spraw załatwianych milcząco nie stosuje się przepisów art. 10 i 79a k.p.a. Nie ulega przy tym wątpliwości, że dodanie do działu II Kodeksu rozdziału 8a o milczącym załatwieniu sprawy powoduje, iż do spraw z tego zakresu stosuje się k.p.a., w tym m.in. art. 28 Kodeksu - o stronie postępowania. Oznacza to, że w sprawach załatwianych milcząco, podobnie jak w przypadku rozstrzyganych decyzją administracyjna, zakres podmiotowy postępowania wyznacza art. 28 k.p.a., stanowiąc, że stroną jest każdy, czyjego interesu prawnego lub obowiązku dotyczy postępowanie albo kto żąda czynności organu ze względu na swój interes prawny lub obowiązek. Zastrzeżenie w art. 122a § 2 k.p.a., że sprawę uznaje się za załatwioną milcząco wówczas, gdy w całości uwzględniono żądanie strony, nie oznacza zatem, że w sprawę zaangażowane są wyłącznie jednorodne interesy strony lub stron wyrażone żądaniem, a także że w sprawę nie będą zaangażowane prawne interesy podmiotów nieskładających żądania. O tym, że dopuszczalne jest milczące załatwienie sprawy w przypadku wielości stron, przesądza regulacja art. 122f $\S 4$ k.p.a. stanowiąca, iż zaświadczenie o milczącym załatwieniu sprawy doręcza się wszystkim stronom w sprawie załatwionej milcząco. W konsekwencji powyższego rodzi się zasadnicze pytanie, w jakim zakresie norma art. 122d § 1 k.p.a. ingeruje w konwencjonalny system gwarancji

\footnotetext{
${ }^{9}$ Por. J. Łętowski, Rada Europy o postępowaniu administracyjnym, "Annales Universitatis Mariae Curie-Skłodowska. Sectio G. Ius" 1993, t. 40, nr 12, s. 93.

${ }^{10}$ Dz.U. poz. 935.
} 
praw strony lub stron przyjęty dla spraw załatwianych $\mathrm{w}$ procesie jurysdykcyjnym.

Punktem wyjścia dla podjętej analizy będzie wskazanie podstawowego standardu dla określenia pozycji procesowej strony w postępowaniu administracyjnym oraz skonfrontowanie z rozwiązaniami instytucji milczącego załatwienia sprawy w zakresie odbiegającym od standardu.

\section{Zasada czynnego udziału strony w ogólnym postępowaniu administracyjnym}

Zasadę ogólną czynnego udziału strony w postępowaniu administracyjnym wyraża art. $10 \S 1$ k.p.a. Zgodnie z jego treścią organy administracji publicznej zobowiązane są zapewnić stronom czynny udział w każdym stadium postępowania, a przed wydaniem decyzji umożliwić im wypowiedzenie się co do zebranych dowodów i materiałów w sprawie oraz zgłoszonych żądań.

W literaturze przedmiotu przyjmuje się, że prawo strony do udziału w każdym stadium postępowania administracyjnego, od momentu jego wszczęcia aż do zakończenia, opiera się na założeniu współpracy strony $\mathrm{z}$ organem $\mathrm{w}$ zakresie ustalenia stanu faktycznego i prawnego sprawy $^{11}$. E. Smoktunowicz podkreśla, że celem regulacji w Kodeksie zasady czynnego udziału strony $\mathrm{w}$ postępowaniu jest nie tylko zapewnienie skuteczności działań administracji, lecz przede wszystkim wpływu strony na rozstrzygnięcie sprawy ${ }^{12}$. Z. Janowicz podnosi, że przepisy k.p.a., ustanawiając prawo strony do czynnego udziału $\mathrm{w}$ postępowaniu, $\mathrm{w}$ istocie statuują swoiste prawo strony do ukształtowania wraz z organem administracji publicznej zarówno przebiegu postępowania, jak i jego wyniku ${ }^{13}$. Podobnie wypowiedział się w tej materii E. Iserzon, wskazując, że udział strony w postępowaniu dowodowym poprzedzającym wydanie orzeczenia jest udziałem w jego tworzeniu ${ }^{14}$.

${ }^{11}$ Por. Z. Janowicz, Ogólne postępowanie administracyjne, Warszawa-Poznań 1978, s. $65 \mathrm{i} \mathrm{n.}$

${ }^{12}$ Por. E. Smoktunowicz, Orzecznictwo Sądu Najwyższego i Naczelnego Sądu Administracyjnego. Kodeks postępowania administracyjnego, Warszawa 1994, s. 11.

${ }_{13}$ Por. Z. Janowicz, Kodeks postępowania administracyjnego. Komentarz, Warszawa 1996, s. 73 i n.

${ }^{14}$ Por. E. Iserzon, Art. 8, w: E. Iserzon, J. Starościak, Kodeks postępowania administracyjnego. Komentarz, teksty, wzory i formularze, Warszawa 1970, s. 58 i n. 
Przejawem zinstytucjonalizowania partycypacyjnej roli jednostki w postępowaniu administracyjnym była nowelizacja k.p.a. dokonana mocą ustawy z dnia 3 grudnia $2010 \mathrm{r} .{ }^{15} \mathrm{~W}$ wyniku zmiany brzmienia art. 7 k.p.a. wyeksponowano rolę strony w procesie dowodzenia, wskazując, że w toku postępowania organy administracji publicznej „z urzędu i na wniosek strony podejmują wszelkie kroki niezbędne do dokładnego wyjaśnienia stanu faktycznego oraz do załatwienia sprawy". W uzasadnieniu projektu tej zmiany k.p.a. słusznie zwrócono uwagę na konieczność aktywizacji strony w toku postępowania, a także zwiększenie jej roli w zbieraniu materiału dowodowego w sprawie ${ }^{16}$. Zmiana ta ściśle związana była z kwestią rozłożenia ciężaru dowodu w postępowaniu administracyjnym. W literaturze przedmiotu oraz $\mathrm{w}$ orzecznictwie niejednokrotnie podkreślano, że strona nie może być zwolniona w procesie $\mathrm{z}$ obowiązku dbałości o własne interesy ${ }^{17}$. Na problem ten zwracano uwagę również w trakcie prac nad przygotowywanym, pod auspicjami Rzecznika Praw Obywatelskich, projektem ustawy - Przepisy ogólne prawa administracyjnego. $\mathrm{W}$ art. 24 projektu proponowano następujące rozwiązanie: "[j]eżeli przepisy prawa wiążą z określonym zachowaniem adresata korzystne dla niego skutki prawne, ciężar udowodnienia zaistnienia okoliczności, od których przepisy prawa uzależniają zaistnienie tych skutków, obciąża tego, kto ma uzyskać korzyść w danej sprawie"18. Z kolei zmianą do Kodeksu z dnia 7 kwietnia 2017 r. wprowadzono do k.p.a. instytucję mediacji, także opartą na założeniu partycypacyjnej roli jednostki w kształtowaniu sfery jej praw uzewnętrznionych aktem kończącym postępowanie.

Prawo strony do czynnego udziału w postępowaniu ma również szczególne znaczenie dla ukształtowania praw jednostki wobec władczej ingerencji organów wykonujących administrację publiczną. W tym

${ }^{15}$ Ustawa z dnia 3 XII 2010 r. o zmianie ustawy - Kodeks postępowania administracyjnego oraz ustawy - Prawo o postępowaniu przed sądami administracyjnymi (Dz.U. 2011 Nr 6, poz. 18).

${ }^{16}$ Por. W. Chróścielewski, W sprawie projektu nowelizacji przepisów k.p.a. dotyczących postępowania ogólnego opracowanego w Ministerstwie Spraw Wewnętrznych i Administracji w 2009 r., w: Instytucje procesu administracyjnego i sadowoadministracyjnego. Ksiega jubileuszowa dedykowana Profesorowi Ludwikowi Żukowskiemu, Przemyśl-Rzeszów 2009, s. 46.

17 Por.: wyrok Naczelnego Sądu Administracyjnego (NSA) z 6 X 1999 r., sygn. III SA 5566/98, ONSA 2000, nr 4, poz. 153; wyrok NSA z 23 VIII 2007 r., sygn. I OSK 1802/06, ONSAiWSA 2008, nr 4, poz. 73.

${ }_{18}$ Por. Prawo do dobrej administracji, Biuletyn RPO, Materiały nr 60, Warszawa 2008, s. 24. 
kontekście zasada czynnego udziału w postępowaniu wiąże się z zasadą transparentności (w procesie administracyjnym ograniczonej do tzw. jawności wewnętrznej postępowania, tj. względem stron i uczestników postępowania na prawach strony), uznawaną za jedną z najważniejszych zasad, na których opiera się współczesny proces ${ }^{19}$. Pełni ona istotne funkcje gwarancyjne i wychowawcze. Wyklucza administrowanie w tajemnicy, poza kontrolą jednostki i kontrolą społeczną; przyczynia się do zwiększenia zaufania do organu administracji publicznej; mobilizuje organ do większej staranności i sumienności przy prowadzeniu postępowania; zmusza do przestrzegania prawa, unikania dowolności i arbitralności ${ }^{20}$.

Na wynikający z art. $10 \S 1$ k.p.a. kontekst zasady czynnego udziału strony w postępowaniu składają się dwie normy prawne: (1) zobowiązująca organ do zapewnienia stronie czynnego udziału w każdym stadium postępowania; (2) zobowiązująca organ do stworzenia stronie możliwości wypowiedzenia się przed wydaniem decyzji co do zebranych dowodów i materiałów oraz zgłoszonych żądań. Z jednej strony można zatem mówić o prawie do udziału w każdej czynności postępowania mającej znaczenie dla rozstrzygnięcia sprawy, w zakresie i na zasadach wyznaczonych dalszymi przepisami k.p.a. Tak określone prawo służy w szczególności pozyskiwaniu wiedzy o postępowaniu, realizacji uprawnienia do monitorowania jego przebiegu, sprawowania kontroli nad tokiem podejmowanych przez organ czynności. Z drugiej strony zasada określona w art. $10 \S 1$ k.p.a. wyraża prawo do wypowiedzenia (wysłuchania), obejmujące w szerszej formule również prawo do inicjatywy dowodowej, żądania informacji i wyjaśnień w toku czynności dowodowych, zadawania pytań, składania oświadczeń, prawo do „ostatniego słowa" - końcowego wypowiedzenia.

W szczególności prawo strony do wysłuchania jest eksponowane jako prawo o dużym ładunku emocjonalnym, związanym z naturalnie zakorzenioną potrzebą wypowiedzenia, uzasadnienia, dowodzenia, któremu ma odpowiadać obowiązek wysłuchania, rozważenia, ustosunkowania. Prawo to jest w procesie gwarantem bezpieczeństwa prawnego jednostki, poczucia zaufania do państwa i prawa, ochrony jednostki przed omnipotencją władzy oraz poszanowania jej godności w toku postępowania.

19 Por. A. Łazarska, Rzetelny proces cywilny, Warszawa 2012, s. 346.

${ }^{20}$ Por. P. Grzegorczyk, K. Weitz, Art. 45 ust. 1 i 2, w: Konstytucja RP, t. 1, pod red. M. Safjana, L. Boska, Warszawa 2016, s. 1141. 
Prawo do wysłuchania, wyodrębniane niekiedy jako samoistna zasada procesowa, bywa również traktowane jako jeden z przejawów realizacji zasady równouprawnienia stron $\mathrm{w}$ procesie, $\mathrm{w}$ tym zasady audi et alteram partem $\mathrm{w}$ rozumieniu prawnie zagwarantowanego udziału jednostki w tworzeniu aktu administracyjnego wobec orzekającego organu. Zdaniem M. Zimmermanna powyższa zasada oznacza równość wobec prawa orzekającego organu administracyjnego oraz jednostki $\mathrm{w}$ tym sensie, że przepisy prawne uprawniające tę jednostkę wiążą także organ orzekający, zapewniając zgodne z prawem załatwienie jej sprawy przy określonym współudziale, obejmującym co najmniej prawo do wypowiedzenia się w sprawie, do stawiania wniosków dowodowych oraz do uruchomienia środków prawnych w przypadku, gdy strona uważa, że jakiekolwiek z jej praw, materialnych czy formalnych, a nawet interesów zostały w postępowaniu czy też w treści zapadłej decyzji naruszone ${ }^{21}$. W obrębie jurysdykcji administracyjnej prawo do wysłuchania zostało zatem wyniesione do rangi procesowej reguły podstawowej, zastrzeżonej dla strony i uczestników na prawach strony $\mathrm{w}$ ich relacjach z organem. W tym ujęciu prawo do wysłuchania składa się na realizację gwarancji czynnego udziału strony w procesie, gwarancji dotarcia do prawdy obiektywnej oraz działania w zaufaniu do organu stosującego prawo. Skorzystanie z prawa do wysłuchania jest uwarunkowane w obrębie reżimu procesowego k.p.a. szczegółowymi uprawnieniami realizującymi cechy prawa. Znajduje swoje uzasadnienie zarówno w czynnościach prawnych stron i uczestników postępowania, np. prezentacji swojego stanowiska przez stronę lub uczestnika postępowania w odpowiedniej formie i w odpowiedni sposób, inicjatywie dowodowej i czynnym udziale w przeprowadzaniu dowodów, jak i w czynnościach materialnotechnicznych sprzyjających realizacji prawa, np. w prawie wglądu do akt sprawy, utrwalaniu czynności postępowania przez organ w celu zapewnienia transparentności postępowania, zawiadomieniach, doręczeniach, wezwaniach. Ich zakres i kształt są zdeterminowane pozycją procesową podmiotu prawa, rodzajem sprawy oraz rodzajem postępowania ${ }^{22}$.

Jednym z założeń praw strony w postępowaniu, wywodzonych z zasady transparentności, jest tzw. jawność wewnętrzna postępowania. Ta

${ }^{21}$ Por. M. Zimmermann, Zasada "audi et alteram partem" $w$ polskim prawie administracyjnym, Referat na I Międzynarodowy Kongres Prawa Porównawczego w Barcelonie, wrzesień 1957 r., materiały niepublikowane, cyt. za: H. Knysiak-Molczyk, op. cit., s. 13.

${ }^{22}$ Por. P. Grzegorczyk, K. Weitz, op. cit., s. 1133 i n. 
formuła jawności znajduje odzwierciedlenie w prawie stron i innych uczestników postępowania do powzięcia wiedzy o postępowaniu i jego przebiegu oraz prawie do pomocy, prawie wglądu do akt sprawy oraz prawie udziału w każdej fazie postępowania. Aktualizuje się zatem wyłącznie względem stron i uczestników postępowania na prawach strony. Regułą w działaniu organów administracji publicznej są posiedzenia niejawne - tzw. gabinetowe; rozprawa stanowi wyjątkową formę jawnego prowadzenia postępowania wyjaśniającego, opartą na przesłankach skatalogowanych w art. 89 k.p.a., z zastrzeżeniem wyłączenia udziału publiczności. Jawność akt sprawy została zastrzeżona wyłącznie dla strony lub podmiotu, któremu przyznano uprawnienia procesowe strony, także po zakończeniu postępowania ${ }^{23}$. Gwarancje czynnego udziału w każdym stadium postępowania z możliwością dokonywania czynności dyspozytywnych w jego toku zastrzeżono dla podmiotu, który korzysta z praw procesowych strony. Szersza formuła jawności w obu prezentowanych konfiguracjach, tj. jawności wewnętrznej i zewnętrznej, aktualizuje się na gruncie procesu administracyjnego wyłącznie na mocy przepisów ustaw szczególnych ${ }^{24}$.

Pozostaje jeszcze istotny wymiar materialny transparentności - tj. otwartość, która uchodzi za jeden z kanonów działania administracji ${ }^{25}$. Rozpatrywana materia łączy się zazwyczaj z prawem dostępu do informacji czy kwestią partycypacji społecznej w procesie administrowania. $\mathrm{W}$ tej mierze Konstytucja ${ }^{26} \mathrm{w}$ art. 61 gwarantuje każdemu obywatelowi m.in. prawo do uzyskiwania informacji o działalności organów władzy publicznej. Podstawowe kanony tego prawa określa zatem sama ustawa zasadnicza. Ich konkretyzacja w ustawach zwykłych dokonała się z chwilą wejścia w życie Ustawy z dnia 6 września 2001 r. o dostępie do informacji publicznej ${ }^{27}$. Również w preambule Rozporządzenia Parlamentu

${ }^{23}$ Zgodnie z art. 73 § 1 k.p.a. strona ma prawo wglądu w akta sprawy, sporządzania z nich notatek, kopii lub odpisów zarówno w trakcie, jak i po zakończeniu postępowania.

${ }^{24}$ Por. np. Ustawa z dnia 3 X 2008 r. o udostępnianiu informacji o środowisku i jego ochronie, udziale społeczeństwa w ochronie środowiska oraz o ocenach oddziaływania na środowisko (tekst jedn. Dz.U. 2018, poz. 2081).

${ }^{25}$ Por. T. Górzyńska, Prawo do informacji i zasada jawności administracyjnej, Kraków 1999, s. 19 i n.; zob. też eadem, Zasada jawności w administracji, „Państwo i Prawo" 1988, z. 6, s. 14. Na temat przejrzystości działań administracji zob. Z. Kmieciak, Ogólne zasady prawa i postępowania administracyjnego, Warszawa 2000, s. 32 i n.

${ }^{26}$ Konstytucja Rzeczypospolitej Polskiej z dnia 2 IV 1997 r. (Dz.U. Nr 78, poz. 483 ze zm.).

${ }^{27}$ Dz.U. 2018, poz. 1330 ze zm. 
Europejskiego i Rady z dnia 30 maja 2001 r. nr 1049/2001 w sprawie publicznego dostępu do dokumentów Parlamentu Europejskiego, Rady i Komisji ${ }^{28}$ stwierdzono, że przejrzystość pozwala obywatelowi na bliższe uczestnictwo $\mathrm{w}$ procesie podejmowania decyzji i gwarantuje, że administracja jest bardziej pracowita i odpowiedzialna względem obywateli w systemie demokratycznym. Przejrzystość przyczynia się do umacniania zasad demokracji i szacunku do praw podstawowych określonych w art. 6 Traktatu o Unii Europejskiej ${ }^{29}$ oraz w Karcie praw podstawowych Unii Europejskiej. Taki wymiar transparentności ma ograniczone zastosowanie $\mathrm{w}$ toku procesu administracyjnego w sprawach indywidualnych. Nie ulega bowiem wątpliwości, że otwartość i przejrzystość działania administracji nie może pozostawać w kolizji z interesami zarówno prywatnymi, jak i publicznymi, które wymagają ochrony. Problem jawności w działaniu administracji musi opierać się zatem na systemie wyważania wartości - z jednej strony transparentności działania administracji w sprawach publicznych, a z drugiej tym, co jako prywatne, niepubliczne, osobiste, intymne bądź wymagające ochrony ze względu na porządek i bezpieczeństwo państwa podlega wyłączeniu z jawności. Jak podkreśla się w literaturze, dotyczy to m.in. akt spraw administracyjnych, czy nawet akt spraw sądowych ${ }^{30}$.

Bardzo ważną rolę w zapewnieniu możliwości urealnienia ochrony jednostki w postępowaniu administracyjnym i gwarancji jej praw w toku rozpoznawania sprawy odgrywa prawo do informacji prawnej i dostępu do pomocy prawnej. Znajomość prawa i związanych z nim procedur ma niezwykle istotne znaczenie dla realizacji praw procesowych strony. $\mathrm{W}$ postępowaniu administracyjnym nie znajduje zastosowania zasada ignorantia iuris nocet; prawo do informacji zaś, a w jego efekcie również prawo do pomocy prawnej jest niezależne od stopnia profesjonalizmu prawnego stron czy ich pełnomocników ${ }^{31}$. To organ pełni funkcję gwaranta bezpieczeństwa prawnego strony w postępowaniu. Prawo to jest postrzegane głównie przez pryzmat zasady ogólnej wyrażonej w art. 9

${ }^{28}$ Dz.Urz. WE L 145/43 z 31 V 2001 r.

${ }^{29}$ Traktat o Unii Europejskiej podpisany 7 II 1992 r. (Dz.Urz. UE C 202 z 7 VI 2016 r.).

${ }^{30}$ Por. G. Sibiga, Dostęp do informacji publicznej a prawa do prywatności jednostki i ochrona jej danych osobowych, "Samorząd Terytorialny” 2003, nr 11, s. 5-6; zob. też idem, Udostepnianie akt sprawy a udostepnianie danych osobowych, "Samorząd Terytorialny" 2003, nr 23; szerzej na ten temat zob. J. Kamińska, M. Rozbicka-Ostrowska, Ustawa o dostępie do informacji publicznej. Komentarz praktyczny, Warszawa 2008, s. 11 i n.

${ }^{31}$ Bliżej na ten temat por. Z. Duniewska, Ignorantia iuris nocet $w$ prawie administracyjnym, Łódź 1998, s. 57 i n. 
k.p.a., na której treść składa się: (1) obowiązek organu prowadzącego postępowanie w sprawie informowania stron o okolicznościach faktycznych i prawnych mogących mieć wpływ na ustalenie ich praw i obowiązków, będących przedmiotem postępowania administracyjnego; (2) obowiązek czuwania nad tym, aby strony i inne osoby uczestniczące $\mathrm{w}$ postępowaniu nie poniosły szkody z powodu nieznajomości prawa i udzielania w tym celu niezbędnych wyjaśnień i wskazówek. Zasada ta jest rozwijana $w$ dalszych przepisach k.p.a., co wydatnie podkreśla jej rangę. Ochrona strony i uczestników postępowania przed skutkami nieznajomości prawa wyznacza zasięg prawa do informacji - opartej na kategorii wyłączenia ignorantia iuris nocet $\mathrm{w}$ toku postępowania (nie może to jednak oznaczać całkowitego zwolnienia strony z dbałości o własną sprawę). W postępowaniu administracyjnym prawo do informacji i pomocy prawnej jest zatem z jednej strony gwarantem i immanentna cechą prawa do procesu postrzeganego przez pryzmat skuteczności ochrony stron $\mathrm{w}$ toku postępowania, $\mathrm{z}$ drugiej zaś elementem budowy zaufania do organu, którego troską jest stworzenie gwarancji ochrony jednostki na drodze postępowania. W myśl art. 8 k.p.a. organy administracji publicznej powinny prowadzić postępowanie „W sposób budzący zaufanie jego uczestników do władzy publicznej”32.

W doktrynie i orzecznictwie prawo do informacji wiąże się również z prawem jednostki do poznania motywów rozstrzygnięcia, określanym jako prawo do uzasadnienia orzeczenia. Uzasadnieniu orzeczenia przypisuje się różne funkcje, w tym m.in.: (1) kontrolne, (2) przekonywające, (3) wychowawcze, (4) legitymizujące, (5) zapewniające transparentność działania władzy. Organ ma nie tylko wydać akt jurysdykcji administracyjnej na podstawie prawa, ale także przekonująco go uzasadnić jako zgodny z prawem. W doktrynie postępowania administracyjnego obowiązek uzasadnienia decyzji jest traktowany jako jedna z ważniejszych gwarancji ochrony interesu indywidualnego jednostki oraz przejaw starannego działania organu zmierzającego do rezultatu - dobrowolnego wykonania decyzji. Obowiązek wskazania motywów rozstrzygnięcia jest więc oceniany przez pryzmat co najmniej kilku zasadniczych funkcji. Po pierwsze, umacnia praworządność w działaniu administracji publicznej poprzez obowiązek wyczerpującego informowania stron

${ }^{32}$ Bliżej na temat praw strony w postępowaniu por. M. Gajda-Durlik, Zasady ogólne postępowania administracyjnego a zasady ogólne postępowania cywilnego, w: System prawa administracyjnego procesowego, pod red. G. Łaszczycy, A. Matana, t. 2, cz. 2: Zasady ogólne postępowania administracyjnego, pod red. J.P. Tarny, W. Piątka, Warszawa 2018, s. 594 i n. 
o okolicznościach faktycznych i prawnych, którymi kierował się organ w toku załatwienia sprawy; w dalszej kolejności jest warunkiem sine qua non skutecznej kontroli wewnątrzadministracyjnej oraz kontroli sądowej aktu stosowania prawa. Po drugie, pełni funkcje wychowawcze i perswazyjne. Przekonanie adresata o słuszności rozstrzygnięcia ma z założenia doprowadzić do dobrowolnego wykonania decyzji bez konieczności stosowania przymusu administracyjnego. Nakaz ten, wywodzony z obowiązku informacyjnego, wiąże się zatem funkcjonalnie z realizacją zasady przekonywania - art. 11 k.p.a., zasady pogłębienia zaufania do organów państwa - art. 8 k.p.a., a także zasady czynnego udziału strony w postępowaniu - art. $10 \S 1$ k.p.a. ${ }^{33}$ Składa się w efekcie na transparentność postępowania traktowaną jako warunek podstawowy publicznego wykonywania władzy państwowej oraz jego rzetelność i skutecznośćc ${ }^{34}$.

\section{Pozycja procesowa strony w postępowaniu w sprawach załatwianych milcząco}

Zgodnie z art. 122d § 1 k.p.a. do spraw załatwianych milcząco nie stosuje się przepisów art. 10 i 79a Kodeksu. Na tle wykładni językowej tego przepisu podnoszona jest w literaturze przedmiotu teza, w myśl której ustawodawca wyłącza w sprawach załatwianych milcząco prawo strony do czynnego udziału w postępowaniu ${ }^{35}$. Pogląd ten znajduje też

${ }^{33}$ Zob. bliżej J. Zimmermann, Motywy decyzji administracyjnej i jej uzasadnienie, Warszawa 1981, s. 149 i n.; zob. też H. Knysiak-Molczyk, op. cit., s. 298 i n.

${ }^{34}$ A. Wiktorowska zwraca uwagę, że zasada przekonywania nie może odnosić się jedynie do aktu kończącego postępowanie (art. 11 k.p.a.), metoda przekonywania może i powinna być stosowana we wszystkich fazach postępowania administracyjnego. Por. A. Wiktorowska, Zasada przekonywania w Kodeksie postępowania administracyjnego, w: Wspótczesne zagadnienia prawa i procedury administracyjnej. Księga jubileuszowa dedykowana Prof. zw. dr. hab. Jackowi M. Langowi, pod red. M. Wierzbowskiego, J. Jagielskiego, A. Wiktorowskiej, E. Stefańskiej, Warszawa 2009, s. 365 i n.

${ }^{35}$ Por. R. Kędziora, Kodeks postępowania administracyjnego. Komentarz, Warszawa 2017, s. 736 i n. Również A. Wróbel zauważa, że wykładnia językowa przepisu art. 122d § 1 k.p.a. mogłaby wskazywać, iż w każdej sprawie, która zgodnie z przepisami szczególnymi mogłaby hipotetycznie być załatwiona milcząco, komentowany przepis wyklucza zastosowanie art. 10 k.p.a., zwłaszcza w kontekście uzasadnienia do projektu zmiany k.p.a. Autor jednak nie uznaje tego stanowiska za zasadne. Por. A. Wróbel, Komentarz do art. 122d § 1, w: Kodeks postępowania administracyjnego. Komentarz, pod red. A. Wróbla, M. Jaśkowskiej, Warszawa 2018, s. 788 i n. 
oparcie w uzasadnieniu nowelizacji, w którym jednoznacznie stwierdzono, że uproszczony charakter trybu milczącego załatwienia sprawy, sprowadzający się do wydania rozstrzygnięcia na podstawie materiału przedstawionego przez strony na etapie wszczęcia postępowania, jak również zakres spraw, które z założenia mają być załatwione w tym trybie, tj. spraw nieskomplikowanych, nie wymaga stosowania zasady czynnego udziału strony w postępowaniu ani jej uszczegółowienia, jaki przewidziano $\mathrm{w}$ projektowanym art. 79a k.p.a. ${ }^{36}$

Stanowisko ustawodawcy w tym względzie nie przekonuje zarówno w kontekście charakteru spraw - zwłaszcza że aktualnie sprawom, które są załatwiane przy wykorzystaniu konstrukcji milczącego załatwienia, nie można absolutnie przypisać cechy sprawy nieskomplikowanej, jak i z punktu widzenia ochrony wartości bardziej podstawowych i zasadniczych, mających walor prawa konstytucyjnego, tj. (1) transparentności postępowania oraz (2) prawa jednostki do procesu. W ich istotę wkomponowane jest prawo strony do czynnego udziału w postępowaniu.

Transparentność - jako istotna współcześnie właściwość postępowania - generuje m.in. takie cechy, jak: jawność, poznawalność, przewidywalność. Z kolei prawo do procesu wyraża uprawnienie do bieżącego udziału w toku postępowania wyjaśniającego, prawo do inicjatywy dowodowej oraz prawo do zapoznania z materiałem dowodowym i wypowiedzenia się co do wyników postępowania wyjaśniającego. Wyartykułowane prawa składają się w efekcie na kontekst standardów podstawowych ochrony praw jednostki w toku postępowania ${ }^{37}$.

Na wstępie rozważań nad zagadnieniem wyłączenia stosowania art. 10 i 79a k.p.a. w sprawach załatwianych milcząco należy jednak zauważyć, że standard podstawowy praw strony w postępowaniu nie jest regułą bezwarunkową. Przejawy racjonalnych ograniczeń notujemy zarówno w ogólnym postępowaniu administracyjnym, jak i w postępowaniach szczególnych, np. w sprawach podatkowych.

Z przepisu art. $10 \S 2$ k.p.a. wynika, że organy administracji publicznej mogą odstąicić od zasady czynnego udziału strony w postępowaniu w rozumieniu art. $10 \S 1$ k.p.a. na zasadzie wyjątku w przypadkach, gdy załatwienie sprawy nie cierpi zwłoki ze względu na niebezpieczeństwo

${ }^{36}$ Por. uzasadnienie do projektu ustawy z dnia 7 kwietnia 2017 r. o zmianie ustawy Kodeks postępowania administracyjnego oraz niektórych innych ustaw, druk sejmowy nr 1183/VIII kadencja, s. 49.

${ }^{37}$ Zob. bliżej A. Łazarska, op. cit., s. 327 i n. Szerzej na ten temat H. Knysiak-Molczyk, op. cit., s. 115 i n. 
dla życia i zdrowia ludzkiego albo ze względu na grożącą niepowetowaną szkodę materialną. Jak zauważa G. Łaszczyca, formuła przepisu określona zwrotem „odstapić od zasady wyrażonej w § 1" oznacza, że uchyleniu podlega zarówno obowiązek ogólny organu zapewnienia czynnego udziału w każdym stadium postępowania, jak i obowiązek konkretny zapewnienia wypowiedzenia się przed wydaniem decyzji ${ }^{38}$. Sytuacje wskazane w przepisie art. 10 § 2 k.p.a. są kwalifikowane w literaturze przedmiotu jako „stan wyższej konieczności w postępowaniu administracyjnym" 39 bądź "wypadek nagłej konieczności"40; podlegają zatem ścisłej wykładni.

Odmiennie ustawodawca uregulował odstępstwa od zasady czynnego udziału strony w postępowaniu w sprawach podatkowych. W myśl art. $123 \S 2$ ustawy - Ordynacja podatkowa ${ }^{41}$ jest to dopuszczalne w sprawach wszczętych na wniosek strony i w warunkach wydania decyzji w całości uwzględniającej jej żądanie. Ponadto jako wyjątki od zasady czynnego udziału strony traktuje się przypadki statuowane normą wynikającą z art. $200 \S 2$ pkt 2 o.p. Dotyczą one nie tylko sytuacji przewidzianych w art. $123 \S 2$ o.p., ale również: (1) ustalania zobowiązań podatkowych, które zgodnie z odrębnymi przepisami ustalane są corocznie, jeżeli stan faktyczny, na podstawie którego ustalono wysokość zobowiązania podatkowego za poprzedni okres, nie uległ zmianie; (2) umorzenia zaległości podatkowych z urzędu; (3) zabezpieczenia; (4) zaliczenia wpłaty, nadpłaty lub zwrotu podatku; (5) wstrzymania wykonania decyzji; (6) stwierdzenia wygaśnięcia decyzji; (7) spraw zabezpieczenia i zastawu skarbowego; (8) zastosowania art. 165 § 7 o.p. wówczas, gdy decyzja ma zostać wydana wyłącznie na podstawie danych zawartych w złożonym zeznaniu, złożonej informacji lub deklaracji. Zwłaszcza zaś w tych przypadkach, gdy rozstrzygnięcie sprawy następuje ze skutkiem korzystnym dla strony lub w zgodzie z jej intencja, ograniczenie zastosowania zasady czynnego udziału strony w procesie stanowi przejaw zracjonalizowania postępowaniu z uwzględnieniem kryterium sprawności.

38 Por. G. Łaszczyca, "Stan wyższej konieczności” w ogólnym postępowaniu administracyjnym, "Samorząd Terytorialny” 2007, nr 4, s. 58.

${ }^{39}$ Ibidem, s. 56.

${ }^{40}$ Por. S. Rozmaryn, O zasadach ogólnych kodeksu postępowania administracyjnego, „Państwo i Prawo" 1961, z. 12, s. 897.

${ }^{41}$ Ustawa z dnia 29 VIII 1997 r. - Ordynacja podatkowa (tekst jedn. Dz.U. 2018, poz. 800 ze zm.), dalej „o.p.”. 
Okazuje się zatem, że zjawisko ograniczania uprawnień strony w procesie i odpowiadających im obowiązków organów administracji publicznej nie jest odosobnione. $W$ konsekwencji pewne racjonalne odstępstwa od gwarancji prawa strony do udziału w postępowaniu w pełnym standardzie wytyczonym k.p.a. - mogą być dopuszczone również w postępowaniu w sprawach załatwianych milcząco. Niemniej jednak wszelkie ograniczenia nie powinny wykraczać poza ramy wyznaczone celem zastosowania instytucji. Nie jest bowiem wykluczona stopniowalność prawa jednostki do czynnego udziału w postępowaniu, ale z zastrzeżeniem działania właściwego organu w taki sposób, aby interes stron nie doznał uszczerbku. Ze względu na okoliczność, że szybkość jest niekiedy wartością dominującą i kierunkową dla rekonstrukcji trybu postępowania w określonych kategoriach spraw, wprowadzenie trybu pilnego na drodze do sprawnego podjęcia rozstrzygnięcia jest uzasadnionym balastem dla tych praw strony do udziału w postępowaniu, które stoją w opozycji do realizacji kryterium szybkości.

Rekonstrukcja zasięgu realizowanego w praktyce uprawnienia do odstąpienia od zasady czynnego udziału strony w sprawach załatwianych milcząco wymaga jednak uwzględnienia, że dotyczyć to będzie spraw i stanów faktycznych odmiennych od dotąd notowanych przypadków. Sytuacje dotychczasowe odstąpienia od reguły bądź opierają się na kategorii „stanu wyższej konieczności”, bądź są pokłosiem uproszczenia procesu w warunkach pełnego zadośćuczynienia żądaniom lub intencjom strony, z jednoczesnym zastrzeżeniem, że występuje - tak jak w sprawach podatkowych - jednopodmiotowość, albo co najmniej jednorodność zaangażowanych w sprawę interesów prawnych. W konsekwencji ukształtowana mocą decyzji sytuacja prawna strony lub stron $\mathrm{w}$ postępowaniu nie stwarza ryzyka ingerencji w sferę praw i wolności innych podmiotów.

Takich gwarancji nie daje natomiast postępowanie w sprawach załatwianych milcząco. Ustawodawca nie wprowadza tutaj reguły jednopodmiotowości, co więcej, wyraźnie wskazuje na wielopodmiotowość w normie wynikającej z art. $122 \mathrm{f} \S 4$ k.p.a. Nie można zatem wykluczyć spornych interesów stron, a także ingerencji praw jednego podmiotu w sferę prawną innego. Jak już zaznaczono na wstępie rozważań, dodanie do działu II Kodeksu rozdziału 8a o milczącym załatwieniu sprawy powoduje, że do spraw z tego zakresu stosuje się k.p.a., w tym m.in. przepisy rozdziału $6 \mathrm{w}$ dziale I Kodeksu - o stronie postępowania. Oznacza to, że analogicznie jak w przypadku spraw rozstrzyganych 
decyzją administracyjną, również w tych sprawach zakres podmiotowy postępowania wyznacza art. 28 k.p.a. W konsekwencji pojęcie "strona” w sferze zastosowania przepisów k.p.a. o milczącym załatwieniu sprawy należy interpretować tak samo jak na gruncie całej regulacji Kodeksu, a więc $z$ uwzględnieniem normatywnej treści art. 28 k.p.a. Z zastrzeżenia uczynionego w art. 122a $\S 2$ k.p.a., zgodnie z którym "[s]prawę uznaje się za załatwioną milcząco w sposób w całości uwzględniający żądanie strony", nie wynika, że w sprawę zaangażowane są wyłącznie jednorodne interesy strony lub stron wyrażone żądaniem, a także że w sprawę nie będą zaangażowane prawne interesy podmiotów nieskładających żądania. Ponadto należy zauważyć, że w zakresie objętym materią rozdziału 8a działu II Kodeksu ustawodawca nie zamieścił normy ograniczającej zakres podmiotowy spraw załatwianych milcząco do takich, w których interes prawny ma dotyczyć tylko jednej strony, tak jak uczynił to np. w rozdziale 14 działu II o postępowaniu uproszczonym $^{42}$. Z kolei o tym, że dopuszczalne jest milczące załatwienie sprawy w przypadku wielości stron, przesądza wprost art. $122 \mathrm{f} \S 4$ k.p.a. stanowiący, że „[z]aświadczenie o milczącym załatwieniu sprawy doręcza się wszystkim stronom w sprawie załatwionej milcząco", a więc podmiotom spełniającym wymogi legitymacji procesowej w rozumieniu art. 28 k.p.a. Biorąc pod uwagę racjonalność ustawodawcy, należy zatem przyjąć brak podstaw prawnych dla założenia jednopodmiotowości postępowania czy jednorodności reprezentowanych w sprawie interesów.

Ponadto w sprawach załatwianych milcząco nie jest przesądzony sposób podjęcia rozstrzygnięcia. Należy uwzględniać zarówno możliwość załatwienia sprawy milcząco w rozumieniu art. 122a § 2 k.p.a., jak i decyzja, postanowieniem, sprzeciwem w drodze decyzji podjętej zgodnie z art. 122b k.p.a. w zw. z art. 122a § 2 k.p.a.

$W$ konsekwencji powyższego kwestia wyznaczenia granic prawa jednostki do postępowania jest istotna dla rekonstrukcji pozycji procesowej $\mathrm{w}$ toku rozpoznawania sprawy podmiotu posiadającego status strony w rozumieniu art. 28 k.p.a. Nie jest to jednak proste zadanie. Redakcja przepisu art. 122d § 1 k.p.a.: "do spraw załatwianych milcząco nie stosuje się przepisów art. 10 i art. 79a" nie daje podstaw do jednoznacznych interpretacji. Przede wszystkim rodzą się następujące pytania: (1) czy ustawodawca, odwołując się do kategorii "sprawa załatwiana milcząco", uwzględnia tylko ten kontekst sytuacyjny, w którym organ,

\footnotetext{
42 Por. art. $163 b$ \& 2 k.p.a.
} 
w następstwie oceny żądania, przesądzi zgodnie z posiadaną kompetencją o takim sposobie załatwienia sprawy; (2) czy też odwołuje się do kategorii „sprawa załatwiana milcząco" w ujęciu generalnym, jako przedmiotu postępowania administracyjnego objętego regulacją k.p.a., i zakłada w związku z tym, że w każdej sprawie, która hipotetycznie, z mocy przepisów szczególnych, może zakończyć się w procesie milcząco, wyłączeniu podlega art. 10 i 79a k.p.a. bez względu na faktyczny rezultat procesu. Odpowiedź na tak zadane pytanie może okazać się kluczowa dla oceny zakresu wyłączenia zastosowania art. 10 i 79a k.p.a.

Dla rozważanego zagadnienia istotny jest fakt, że nie każda sprawa objęta przedmiotem regulacji k.p.a. z tego powodu, iż może zakończyć się w sposób milczący w myśl przepisów ustaw szczególnych, będzie finalizowana w ten właśnie sposób. Nie ulega bowiem wątpliwości, że instytucja milczącego załatwienia sprawy w zakresie objętym przedmiotem regulacji k.p.a. jest ściśle powiązana z prawem organu do załatwienia sprawy decyzją lub postanowieniem kończącym postępowanie. W terminie miesiąca od dnia złożenia żądania lub w innym terminie określonym $w$ przepisach szczególnych organ może wydać decyzję, postanowienie kończące postępowanie w sprawie lub wnieść sprzeciw w drodze decyzji. W tej sytuacji, gdyby przyjąć twierdzenie jak w punkcie pierwszym, tj. że wyłączenie czynnego udziału strony w procesie dotyczy wyłącznie jego finalizacji w sposób milczący, w każdym przypadku, gdy organ wydałby jednak akt konwencjonalny, prowadzenie postępowania z pominięciem przepisu art. 10 i 79a k.p.a. prowadziłoby wprost do naruszenia prawa strony do czynnego udziału w postępowaniu. Warto zaznaczyć, że w literaturze przedmiotu przeważa twierdzenie oparte na takim właśnie założeniu. Podnosi się m.in., że normę wyprowadzoną z art. 122d § 1 k.p.a. należy odczytywać jako wyjątek, stąd też konieczna jest jej ścisła, a nawet zawężająca interpretacja. $Z$ tego względu należy przyjąć, że wyłączenie stosowania przepisu art. 10 oraz 79a k.p.a. odnosi się tylko do tej sytuacji, w której organ rzeczywiście zamierza zakończyć postępowanie $\mathrm{w}$ drodze milczenia $^{43}$, a nawet że wyłączenie to dotyczy postępowania, które od dnia doręczenia organowi żądania strony do dnia upływu terminu na wydanie decyzji, postanowienia lub wniesienia sprzeciwu jest prowadzone w celu milczącego załatwienia sprawy ${ }^{44}$. W przypadku, w którym organ

${ }^{43}$ Por. J. Piecha, Art. 122d § 1 i 2, w: Kodeks postępowania administracyjnego, Komentarz, pod red. R. Hausera, M. Wierzbowskiego, Warszawa 2017, s. 911.

${ }^{44}$ A. Wróbel, op. cit., s. 789. 
dochodzi do przekonania, że w danej sprawie konieczne jest wydanie decyzji administracyjnej, postanowienia kończącego postępowanie $\mathrm{w}$ sprawie lub wniesienie sprzeciwu, przepis art. 122d § 1 k.p.a. nie znajdzie zastosowania ${ }^{45}$.

W kontekście brzmienia przepisu art. 122d § 1 k.p.a. nie jest wykluczona również odmienna interpretacja, a mianowicie zakładająca, że ustawodawca, stanowiąc "do spraw załatwianych milcząco", odwołuje się w istocie do sprawy jako kategorii materialnoprawnej, dla której dopuszcza się możliwość milczącego załatwienia w warunkach uwzględnienia żądania, a jednocześnie przewiduje formę decyzji, postanowienia jako przejaw negacji dla treści żądania, bądź też jako alternatywę dla milczenia. Wbrew pozorom taka interpretacja nie jest pozbawiona logicznego uzasadnienia, chociażby w kontekście wyłączenia z zastosowania przepisu art. 79a k.p.a. Powstaje bowiem pytanie, jakie intencje przyświecały ustawodawcy przy wprowadzeniu normy statuującej zastrzeżenie niestosowania, obok art. 10 k.p.a., także art. 79a k.p.a. Zgodnie z przepisem art. 79a k.p.a. „w postępowaniu wszczętym na żądanie strony, informując o możliwości wypowiedzenia się co do zebranych dowodów i materiałów oraz zgłoszonych żądań, organ administracji publicznej jest obowiązany do wskazania przesłanek zależnych od strony, które nie zostały na dzień wysłania informacji spełnione lub wykazane, co może skutkować wydaniem decyzji niezgodnej z żądaniem strony". Zastosowanie przepisu dotyczy wyłącznie fazy finalizacji postępowania, tj.: (1) następuje po zakończeniu zbierania dowodów i materiałów w sprawie, a przed wydaniem decyzji; (2) odnosi się do wykazania przesłanek zależnych od strony, które nie zostały spełnione lub wykazane najpóźniej na dzień wysyłania informacji; (3) opiera się na założeniu związku przyczynowo-skutkowego pomiędzy brakiem spełnienia lub wykazania przesłanek zależnych od strony a możliwością wydania decyzji niezgodnej z jej żądaniem.

Ze względu na okoliczność, że milczące załatwienie sprawy, jako forma działania administracji, jest równoznaczne z rozstrzygnięciem w pełni uwzględniającym żądanie strony, naturalny jest brak sfery odniesienia art. 79a k.p.a. W konsekwencji, w warunkach przyjęcia pierwszego założenia, ustawodawcy należałoby zatem postawić zarzut braku racjonalności. Przyjęcie natomiast zakresu zastosowania statuowanej normy wyłączającej art. 79a k.p.a. do "spraw załatwianych milcząco",

\footnotetext{
${ }^{45}$ Por. J. Piecha, op. cit., s. 911.
} 
jako kategorii materialnoprawnej, objętej przedmiotem obowiązywania k.p.a., oznaczałoby w istocie, że przepis art. $122 \mathrm{~d} \S 1$ k.p.a. opiera się na racjonalnym założeniu wyłączenia zastosowania art. 79a k.p.a. w sprawie, dla której istnieje możliwość milczącego załatwienia w warunkach uwzględnienia żądania, ale jednocześnie nie można wykluczyć wydania decyzji, postanowienia kończącego postępowanie albo wniesienia sprzeciwu - a zatem aktów niezgodnych z żądaniem.

Inną kwestią wymagającą rozważenia jest zakres wyłączenia praw strony do udziału $\mathrm{w}$ procesie. Jak już zaznaczono, z przepisu art. $10 \S 1$ k.p.a. można wyprowadzić dwie normy: (1) dotyczącą udziału strony w bieżącym postępowaniu, kiedy nie zakończono jeszcze zbierania dowodów i materiałów w sprawie; (2) dotyczącą prawa strony do zapoznania się ze zgromadzonym materiałem w sprawie i końcowego wypowiedzenia. W literaturze przedmiotu podkreśla się z kolei, że rozwiązań proceduralnych, na mocy których strona korzysta z gwarancji ochrony praw w procesie, jest w Kodeksie znacznie więcej niż tylko te upatrywane $w$ regule opisanej w art. $10 \S 1$ k.p.a. ${ }^{46}$ Zgodnie $z$ art. 81 Kodeksu okoliczność faktyczna może być uznana za udowodniona, jeżeli strona miała możliwość wypowiedzenia się co do przeprowadzonych dowodów, chyba że zachodzą okoliczności, o których mowa w art. 10 $\S 2$ k.p.a. Prawo do wypowiedzenia się przez stronę realizowane jest także: w zakresie składania wyjaśnień w toku przeprowadzania dowodu z zeznań świadków, opinii biegłych lub w toku oględzin (art. 79 § 2 k.p.a.); w związku z prawem do zadawania pytań świadkom, biegłym oraz stronom (art. $79 \S 2$ k.p.a.); w zakresie składania oświadczeń, gdy przepis prawa nie wymaga potwierdzenia określonego faktu lub stanu prawnego w drodze zaświadczenia (art. $75 \S 1$ k.p.a.); w zakresie składania wyjaśnień, zgłaszania żądań, propozycji i zarzutów oraz przedstawiania dowodów na ich poparcie w toku prowadzonej rozprawy (art. $95 \S 1$ k.p.a.). Organ jest w tym przypadku gwarantem realizacji praw strony poprzez obowiązek zawiadomienia w określonym trybie i terminie o przeprowadzeniu dowodu lub postępowania dowodowego $\mathrm{w}$ formie rozprawy $\mathrm{z}$ jednoczesnym zapewnieniem czynnego udziału w czynnościach postępowania. Ponadto pozostaje jeszcze: prawo strony do inicjatywy dowodowej; prawo dostępu do dotyczącej jej dokumentacji; prawo do przeglądania akt sprawy zarówno w toku, jak

${ }^{46}$ Por. R. Sawuła, Audiatur et altera pars w procesie administracyjnym i sadowoadministracyjnym, "Casus” 2010, nr 55, s. 10. 
i po zakończeniu postępowania; prawo do informacji i pomocy prawnej; prawo do poznania motywów rozstrzygnięcia; prawo do żądania sprostowania, uzupełnienia lub wyjaśnienia co do treści decyzji.

Jeżeli zatem przyjąć założenie, że przepis art. $122 \mathrm{~d} \S 1$ k.p.a., stanowiąc "do spraw załatwianych milcząco", odwołuje się w istocie do sprawy jako kategorii materialnoprawnej, dla której dopuszcza się możliwość milczącego załatwienia w warunkach uwzględnienia żądania, a jednocześnie przewiduje formę decyzji, postanowienia jako przejaw negacji treści żądania bądź jako alternatywę dla milczenia, to wówczas prawa strony do czynnego udziału w postępowaniu należy wywodzić $\mathrm{w}$ równej mierze $z$ art. $10 \S 1$ k.p.a., jak i dalszych przepisów Kodeksu. Podkreślenia wymaga bowiem fakt, że przepis art. $10 \S 1$ k.p.a. pełni dwie funkcje: (1) ma charakter normatywny w tym sensie, że zawiera normy nadające się do bezpośredniego, samoistnego zastosowania (taki wymiar ma umożliwienie wypowiedzenia się przed wydaniem decyzji co do zebranych dowodów, materiałów oraz zgłoszonych żądań), a jednocześnie (2) wypełnia funkcję zasady, normy przewodniej - reguły interpretacyjnej, wiążącej dyrektywy stosowania szczegółowych regulacji prawnych Kodeksu ${ }^{47}$. W tym też znaczeniu art. $10 \S 1$ k.p.a., będąc nośnikiem zasady ogólnej czynnego udziału strony w każdym stadium postępowania, w istocie dostarcza wiążących wskazówek interpretacyjnych pozwalających na lepsze zrozumienie sensu unormowań proceduralnych i ich prawidłowe realizowanie w praktyce ${ }^{48}$. W konsekwencji zastrzeżenie uczynione $\mathrm{w}$ art. $122 \mathrm{~d} \S 1$ k.p.a. o niestosowaniu art. 10 i 79a do spraw załatwianych milczaco nie uchyla stosowania, w zakresie adekwatnym do okoliczności konkretnego stanu faktycznego, tych przepisów k.p.a., które wyrażają określone prawa strony w toku postępowania. Wyraźne ograniczenie klauzuli derogacyjnej art. 122d § 1 k.p.a. poprzez zastrzeżenie o niestosowaniu art. 10 i 79a k.p.a. oznacza a contrario dopuszczalność i powinność stosowania niepodlegających wyłączeniu przepisów o prawach strony w toku postępowania w stopniu podyktowanym rodzajem spraw, okolicznościami związanymi z procesem wyjaśniania, zakresem podejmowanych czynności, natury i zaangażowanych interesów stron postępowania.

W konsekwencji należy przyjąć, że prawo strony do końcowego zapoznania się z materiałem dowodowym, jak i prawo do „ostatniego

${ }^{47}$ Bliżej na ten temat por. J.P. Tarno, Zasady ogólne k.p.a. w orzecznictwie Naczelnego Sadu Administracyjnego, "Studia Prawno-Ekonomiczne” 1986, t. 36, s. 63.

${ }^{48}$ Por. J. Służewski, Postępowanie administracyjne, Warszawa 1982, s. 43. 
słowa" w postępowaniu, uszczegółowione dodatkowo, wywodzonym z art. 79a § 1 i 2 k.p.a., prawem do wykazania lub spełnienia przesłanek zależnych od strony, mających wpływ na treść korzystnego rozstrzygnięcia, jako stanowiące istotny balast dla szybkiego i skutecznego załatwienia sprawy w warunkach stosowania instytucji milczenia, wyznaczają przedmiotowy zakres ograniczenia praw strony w postępowaniu. Dotyczy to przy tym w równym stopniu rozstrzygnięcia milczącego, jak i rozstrzygnięcia decyzją lub postanowieniem.

\section{Podsumowanie}

W warunkach zastosowania instytucji milczenia optymalna wydaje się zatem interpretacja oparta na następujących twierdzeniach: (1) przepis art. 122 d $\S 1$ k.p.a. odwołuje się do kategorii "sprawa załatwiana milcząco" w ujęciu materialnoprawnym jako przedmiotu postępowania administracyjnego objętego regulacją k.p.a. i zakłada w związku z tym, że w każdej sprawie, która hipotetycznie, z mocy przepisów szczególnych, może zakończyć się w postępowaniu milcząco, wyłączeniu podlega art. 10 i 79a k.p.a. bez względu na faktyczny rezultat procesu; (2) przepis art. 122d $\S 1$ k.p.a. wyłącza jedynie prawo strony do końcowego zapoznania się z zawartym w aktach materiałem dowodowym i prawo końcowego wypowiedzenia, jak również wyłącza po stronie organu, wynikający z art. 79a $\S 1$ k.p.a., obowiązek wskazania stronie niespełnionych lub niewykazanych przesłanek od niej zależnych i mających wpływ na rozstrzygnięcie sprawy zgodnie z wolą strony ${ }^{49}$. W konsekwencji jednostka jest wyposażona w wiele praw proceduralnych gwarantujących zachowanie jej statusu w toku postępowania, podlegają one jednak pewnym ograniczeniom w świetle sprawności i skuteczności w osiąganiu przez administrację swoich celów, wyłącznie wszakże w zakresie wyznaczonym normą wynikająca z art. $122 \mathrm{~d} \S 1$ k.p.a. ${ }^{50}$

Nie ulega wątpliwości, że obowiązek poszanowania i ochrony praw strony w postępowaniu jest związany z realizacją zasady demokratycznego państwa prawnego, w tym z realizacją zasady legalności, transparentności i rzetelności działania władz publicznych. Gwarancje ściśle

\footnotetext{
${ }^{49} \mathrm{~W}$ tej materii podobne stanowisko prezentuje J. Piecha, op. cit., s. 910 i n.

${ }^{50} \mathrm{Na}$ temat statusu prawnego jednostki w postępowaniu administracyjnym w kontekście np. postępowań sądowych zob. T.T. Koncewicz, Sądowa sprawiedliwość proceduralna w prawie europejskim, "Gdańskie Studia Prawnicze” 2016, t. 35, s. 251 i n.
} 
proceduralne, zawierające się $\mathrm{w}$ prawie strony do bycia wysłuchanym, prawie do pomocy i informacji, prawie dostępu do procesu, prawie do poznania motywów działania, prawie do obrony, prawie do poufności informacji, prawie do skutecznego środka zaskarżania, są doceniane z perspektywy proceduralnej, bez względu na rezultat procesu. Optyka ochrony jednostki, wyrażona w jej prawach proceduralnych, wyznacza bowiem drogę odchodzenia od perspektywy wyłącznie formalistycznej, wyznaczonej dokładnością, słusznością, brakiem błędów w stosowaniu prawa, na rzecz inherentnej wagi praw proceduralnych ${ }^{51}$. W tym rozumieniu prawa proceduralne jednostki, wyznaczające cechy zasady czynnego udziału w procesie, pozostają w służebnej roli wobec praw podmiotowych jednostki o charakterze materialnym, a jednocześnie jako takie są kwalifikowane jako prawa podmiotowe jednostki, będące jedną z gwarancji jej statusu prawnego w toku postępowania ${ }^{52}$.

\section{THE GENERAL PRINCIPLE OF ACTIVE PARTICIPATION OF A PARTY IN ADMINISTRATIVE PROCEEDINGS AND THE RIGHTS OF A PARTY IN PROCEEDINGS IN CASES SETTLED QUIETLY}

\section{Sum mary}

Pursuant to the amendment to the Code of Administrative Procedure, the Act of 7 April 2017 amending the Act - The Code of Administrative Procedure and certain other acts, the settling of a matter quietly has been incorporated into the framework of this Code. The legislator reserved a peculiar procedural regime for cases settled quietly, based on the formula of simplified, de-formalised proceedings, with simultaneous setting of limits for the rights of the party in the trial. Pursuant to Article $122 \mathrm{~d} \S 1$ of the Code of Administrative Procedure, the provisions of Articles 10 and 79a of the Code of Administrative Procedure shall not apply to matters settled quietly. There is no doubt that the addition to Section II of the Code of Administrative Procedure of Chapter 8a on quiet settlement of matters results in the application of the Code of Administrative Procedure to matters within this scope, including, inter

${ }^{51}$ Por. T.T. Koncewicz, Aksjologia Unijnego Kodeksu Proceduralnego, Warszawa 2010, s. 70 i n.

${ }^{52}$ A. Łazarska, op. cit., s. 66. A. Krawczyk traktuje w kategoriach prawa podmiotowego o charakterze podstawowym prawo jednostki do procesu w standardach dobrej praktyki administracyjnej. Zob. A. Krawczyk, Standardy wspótczesnej regulacji postępowania administracyjnego, w: Prawo procesowe administracyjne, seria System prawa administracyjnego, pod red. R. Hausera, Z. Niewiadomskiego, A. Wróbla, t. 9, Warszawa 2017, s. 35 i n.; M. Gajda-Durlik, Zasada sprawiedliwości proceduralnej, w: System prawa administracyjnego procesowego, pod red. G. Łaszczycy, A. Matana, t. 2, cz. 2: Zasady ogólne postępowania administracyjnego, s. 503 i n. 
alia, Article 28 of the Code - on the side of proceedings. This means that in matters settled quietly, similarly as in the case of matters settled by an administrative decision, the subjective scope of proceedings is determined by Article 28 of the Code of Administrative Procedure, stating that each party is a party whose legal interest or duty the proceedings relate to, or who demands the authority to act due to its legal interest or duty. At the same time, the reservation made in Art. 122a $\S 2$ of the Code of Administrative Procedure that a case is deemed to have been settled quietly when the party's claim has been fully accepted does not mean in practice that only homogeneous interests of the party or parties expressed in the claim are involved in the case, and that the legal interests of subjects not filing a claim will not be involved in the case. As a consequence of the above, the fundamental question arises as to what extent the provision of Article $122 \mathrm{~d}(1)$ of the Code of Administrative Procedure interferes with the conventional system of guaranteeing the rights of a party or parties adopted for cases settled in the jurisdiction process. The starting point of the analysis is the identification of the basic standard for determining the procedural position of a party in administrative proceedings, and then confronting with the solutions of the institution of quiet settlement of the matter in the scope different from the standard.

Keywords: party to proceedings - principle of active participation of a party in proceedings - institution of a quiet settlement of a case 